\title{
Low birth weight newborn: epidemiological, therapeutic and evolutive aspects in the commune of Kara (TOGO) from 2014 to 2015
}

\author{
Azoumah K.D ${ }^{1}$, Segbedji K.A.R ${ }^{2}$, Douti K.N ${ }^{3}$, Ahouankpo K.A ${ }^{4}$, Tchagbele O.B ${ }^{5}$, Geraldo $A^{6}$, Douaguibe \\ B $^{7}$, Balaka B ${ }^{8}$, Agbere A.D. ${ }^{9}$
}

${ }^{1}$ Dr. Azoumah KD, Senior Lecturer of Pediatrics, Kara Teaching Hospital, ${ }^{2}$ Dr. Segbedji KAR; Clinical Head Assistant of Pediatrics, Kara Teaching Hospital, ${ }^{3}$ Dr. Douti KN, Senior Lecturer of Pediatrics; Lomé Campus Teaching Hospital, ${ }^{4}$ Dr. Ahouankpo KA, Medical Doctor; Lomé Sylvanus Olympio Teaching Hospital, ${ }^{5}$ Dr. Tchagbele OB, Pediatrician; Lomé Sylvanus Olympio Teaching Hospital, ${ }^{6}$ Dr. Geraldo A, Clinical Head Assistant of Pediatrics, Kara Teaching Hospital, ${ }^{7}$ Dr. Douaguibe B, Clinical Head Assistant of Gynecology and Obstetrics, Lomé Campus Teaching Hospital, ${ }^{8}$ Dr. Balaka B, Professor of Pediatrics; Lomé Campus Teaching Hospital, ${ }^{9}$ Dr. Agbere AD, Professor of Pediatrics; Lomé Sylvanus Olympio Teaching Hospital.

Address for Correspondence: Dr.Azoumah K.D. E-mail: adkazoum@yahoo.fr / adkazoum@gmail.com

\begin{abstract}
Introduction: Low birth weight (LBW) is the third leading cause of neonatal death after neonatal infections and asphyxia. Objective: Describe the epidemiological, therapeutic and evolutionary effects of LBW neonates. Methods: This was an analytical retrospective study from January 1, 2014 to December 31, 2015, in three neonatal units in Kara commune concerning the LBW newborn. The main parameters studied were clinical, therapeutic and evolutionary. Results: Of 1712 newborns hospitalized, 527 were LBW (30.8\%) of which 451 were included with 222 males (sex ratio 0.97). The average birth weight was $1775.72 \mathrm{~g}$. Delivery was carried out through caesarean section in $16.9 \%$ mainly did about eclampsia $(29.5 \%)$ and prævia hemorrhagic placenta $(12.6 \%)$. The main co-morbidities were neonatal infections $(55.4 \%)$ and perinatal asphyxia $(12.9 \%)$. The treatment consisted of an antibiotic therapy $(73.8 \%)$, an exclusive breastfeeding $(43.7 \%)$ and Kangaroo Maternal Care (30.2\%). Immediate results were marked by deaths in $18.8 \%$ after an average of 6 days hospital admission. The main factors significantly related to neonatal mortality were the early neonatal period, low sucking, hypotonia, high preterm birth, very LBW, inadequate pregnancy monitoring, referrals, perinatal asphyxia, artificial breastfeeding. Conclusion: The incidence of LBW remains high with significant mortality due to preventable factors, requiring actions to be coordinated from conception through the end of the period to improve the survival of these newborns.
\end{abstract}

Key words: Low-birth-weight, newborn, morbidity, outcomes, Togo.

\section{Introduction}

Neonatal infections, low birth weight (LBW) and perinatal asphyxia are the three leading causes of neonatal deaths $[1,2]$ in developing countries. In Africa between 1998 and 2008, the prevalence of LBW varied from 7 to $17 \%$ depending on the areas and periods of study[3]. LBW is a multifactorial health problem for which the prevention is possible through targeted interventions on modifiable factors

Manuscript received: $8^{\text {th }}$ December 2017

Reviewed: $18^{\text {th }}$ December 2017

Author Corrected: $26^{\text {th }}$ December 2017

Accepted for Publication: $31^{\text {st }}$ December 2017
[4, 5]. In Togo, in 2013, neonatal mortality was $2.7 \%$. Newborns accounted for $32.3 \%$ deaths among of children under five and $11.6 \%$ of these deaths were premature births and LBW neonates [6]. Most of the LBW studies in Togo were conducted in Lomé $[7,8]$. We have carried out this study in order to assess the situation of the LBW in Kara, a region in the northern Togo. Our objective was to describe the epidemiological, therapeutic and evolutionary aspects of LBW in the pediatric ward in Kara commune. 


\section{Materials and Method}

Place of study: The study was carried out in the city of Kara, $420 \mathrm{~km}$ north of Lomé, in the pediatrics departments respectively at Kara Teaching Hospital, Regional Hospital of Kara-Tomdè and the SOS-VE Mother and Children Hospital of Kara,

which are the main centres of reference and children's hospitalisation.

Type and period of study: It was a retrospective analytical review of LBWs' records in these units from January 1, 2014 to December 31, 2015 (24 months).

\section{Results}

Out of the 1712 newborns identified in the three centres surveyed, 527 had LBW(30.8\%) of which 451 met our inclusion criteria. They were divided into 222 boys and 229 girls (sex ratio of 0.97). Hypotrophic newborns accounted for $34.9 \%$ of the lbws and premature babies, $65.1 \%$.

Perinatal data- The average parity $(\mathrm{n}=208$ cases) of LBW mothers was 2.80 children per woman (extreme from one to ten), 98 mothers were primipara (31.9\%) and 39 were large multipara (14.44\%). In the mothers' histories, we counted 30 cases of abortions, 10 high blood pressure cases (HPB), three cases of uterine scarring, two cases of LBW and two cases of multiple pregnancies.

The number of prenatal consults(n=205 cases) in LBW pregnancy follow-up ranged from one to nine with an average of three prenatal consults. The weeks of pregnancy $(n=212$ cases) ranged from 24 to 42 weeks.

The very premature babies (gestational age under 33 weeks) accounted for $52.8 \%$ of LBW, the preterm infants of 34 at 36 weeks of gestational age represented 12.3\%. Of the 451 LBW newborns surveyed, 104 were from multiple pregnancies $(23.1 \%)$ of which $98.1 \%$ are twins.

These pregnancies have been marked by a number of some pathologies: viral hepatitis B (12 cases), HIV infection (11 cases), malaria ( 3 cases), toxoplasmosis (1 case), and asthma attack ( 1 case).

With regard to the place of birth $(n=386)$, childbirth occurred at the maternity of the three studied centres in 288 cases $(63.9 \%)$, in other health facilities in 80 cases $(17.7 \%)$ and at home in 18 cases (4\%). The delivery was performed through vaginal in 375 cases $(83.1 \%)$ and by caesarean section in 76 cases $(16.9 \%)$.

Eclamptic seizures (27.6\%), anamnios or severe oligoamnios (11.8\%), previa hemorrhagic placenta $(11.8 \%)$, excessive uterine height $(9.2 \%)$ and acute fetal distress $(9.2 \%)$ were the main indications of caesarean sections, to a lesser extent neglected shoulders $(5.3 \%)$ and bi-cicatricial uterus $(5.3 \%)$.

Clinical data- The Apgar score at birth was reported in 245 cases. It was less than 7 in 58 cases (23.7\%) at the first minute (of which 10 in apparent state of death), in 28 cases at the $5^{\text {th }}$ minute and in 12 cases at the $10^{\text {th }}$ minute.

The neonatal resuscitation has been reported in 33 cases. Birth weight $(n=445$ cases $)$ ranged from $750 \mathrm{~g}$ to 2475 $\mathrm{g}$ with an average of $1775.72 \pm 408,75 \mathrm{~g}$.

LBW from 1500 to $1999 \mathrm{~g}$ represented 148 cases (48.83\%), very LBW from 1000 to $1499 \mathrm{~g}$ represented 93 cases $(20.9 \%)$ and extreme LBW (750-999g) constituted 9 cases $(2 \%)$. 


\section{Original Research Article}

The size of these LBW newborn ranged from $27 \mathrm{~cm}$ to $50 \mathrm{~cm}$ with an average of $41.75 \mathrm{~cm}$. Clinically, 135 cases were identified $(29.9 \%)$ of hypothermia $\left(<36^{\circ} \mathrm{C}\right)$ and 117 cases of fever $(25.9 \%)$. Some pathologies were mainly associated with LBW at their admission: neonatal infections (55.4\%) and perinatal asphyxia (12.9\%), neonatal respiratory distress $(2.9 \%)$, haemorrhagic diseases of the newborn $(1.1 \%)$, congenital malformation $(0.9 \%)$, anemia $(0.4 \%)$ and dehydration $(0.4 \%)$.

Data relating to care and support- The time frame for transferring LBW between maternity and neonatal services at the same centre varied from 5 minutes to 48 hours. This delay was on average 12 hours in the case of referral from a maternity ward to that of neonatology of another centre; $55.65 \%$ of LBWs (251 cases) were transferred within the first 24 hours.

The care received by these newborns was essentially a metabolic contribution by glucosate serum $(78.0 \%)$, a heating with plate or incubator (76.7\%), antibiotic therapy (73.8\%), exclusive breastfeeding (43.7\%), and Kangaroo Mother Care or KMC (30.2\%). The antibiotic treatment consisted mainly of a double antibiotic therapy $(63.4 \%)$ combining gentamycin for three to five days and ceftriaxone or cefotaxime (Table-I).

Outcome data- The discharge weight ranged from 700 to $2920 \mathrm{~g}$ with an average hospitalization time of $6.07 \pm$ 4.7 days (one to 30 days).

The evolution was favorable in 302 cases (67\%), 85 LBW had died (18.8\%) and therest being escapes or exits against medical advice (14.2\%). A variety of pregnancy-obstetrical factors have been associated with LBW's mortality.

Inadequate pregnancy monitoring, referrals of LBW from another centre, high prematurity, veryLBWand perinatal asphyxia were the main factors significantly related to death (Table-II).

Table-I: Distribution of low birth weight based on treatment received.

\begin{tabular}{|c|c|c|}
\hline Treatment & Number & Percentage \\
\hline Glucosate serum & $\mathbf{3 5 2}$ & $\mathbf{7 8 . 0}$ \\
\hline Warm-up by plate-warming or incubator & $\mathbf{3 4 6}$ & 73.8 \\
\hline Antibiotics & 333 & 43.5 \\
\hline Gentamycin & 333 & 37.5 \\
\hline Cefotaxime & 196 & 04.2 \\
\hline Ceftriaxone & 169 & 13.7 \\
\hline Ceftriaxone then cefotaxime & 19 & $\mathbf{4 3 . 7}$ \\
\hline Ampicillin & $\mathbf{3 0 . 2}$ & 15.1 \\
\hline Breastfeeding & $\mathbf{1 9 7}$ & 15.1 \\
\hline Oxygenation & 68 & 12.9 \\
\hline Antipyretic & 68 & 04.0 \\
\hline Multivitamins & 58 & 02.4 \\
\hline Vitamin K1 & 18 & 00,9 \\
\hline Anticonvulsant & 11 & 00.2 \\
\hline Aspiration & 04 & \\
\hline Phototherapy & 01 & \\
\hline
\end{tabular}


Table-II: Development of low birth weight based on pregnancy-obstetrical data.

\begin{tabular}{|c|c|c|c|c|c|}
\hline Pregnancy-obstetrical data & Death & Cure & Unknown & Total & Value of $p$ \\
\hline \multicolumn{6}{|c|}{ Partitioning } \\
\hline$[0-3]$ & 31 & 117 & 21 & 169 & 0,30 \\
\hline [4-10] & 4 & 32 & 3 & 39 & \\
\hline Unspecified & 50 & 153 & 40 & 243 & \\
\hline \multicolumn{6}{|c|}{ Twinness } \\
\hline Yes & 69 & 223 & 53 & 345 & 0,25 \\
\hline No & 16 & 79 & 11 & 106 & \\
\hline \multicolumn{6}{|c|}{ Antenatal visits } \\
\hline$[0-3]$ & 26 & 111 & 17 & 154 & $\mathbf{0 , 0 2 0 3}$ \\
\hline 4 and more & 3 & 41 & 7 & 51 & \\
\hline Unspecified & 56 & 150 & 40 & 246 & \\
\hline \multicolumn{6}{|c|}{ HIV serology } \\
\hline Positive & 5 & 5 & 1 & 11 & \\
\hline Negative & 14 & 69 & 7 & 90 & $\mathbf{0 , 0 5 7}$ \\
\hline Unspecified & 66 & 228 & 56 & 350 & \\
\hline \multicolumn{6}{|c|}{ Admission method } \\
\hline Internal transfer & 37 & 219 & 32 & 288 & 0,000007 \\
\hline Referral / consultation & 23 & 50 & 25 & 98 & \\
\hline Unspecified & 25 & 33 & 7 & 65 & \\
\hline \multicolumn{6}{|c|}{ Weeks of Pregnancy } \\
\hline$[24-32]$ & 25 & 65 & 5 & 95 & 0,0017 \\
\hline$[33-36]$ & 7 & 33 & 3 & 43 & \\
\hline$[37-42]$ & 4 & 54 & 16 & 74 & \\
\hline Unspecified & 49 & 150 & 40 & 239 & \\
\hline \multicolumn{6}{|l|}{ Delivery method } \\
\hline Vaginale & 77 & 237 & 61 & 375 & 0,042 \\
\hline Caesarean section & 8 & 65 & 3 & 76 & \\
\hline \multicolumn{6}{|l|}{ Perinatal asphyxia } \\
\hline Yes & 14 & 13 & 0 & 27 & 0,000002 \\
\hline No & 21 & 167 & 30 & 218 & \\
\hline Unspecified & 50 & 122 & 34 & 206 & \\
\hline \multicolumn{6}{|l|}{ Birth weight (g) } \\
\hline [750-999] & 5 & 3 & 1 & 9 & 0,0000003 \\
\hline [1000-1449] & 28 & 57 & 8 & 93 & \\
\hline [1500-2499] & 47 & 241 & 55 & 343 & \\
\hline Unspecified & 5 & 1 & 0 & 6 & \\
\hline
\end{tabular}

Therapeutically, mortality was significantly related to artificial breastfeeding, insufficient intake of calories (glucosate serum), first week of hospitalization, and LBW less than 7 days old (Table III). 
Table-III: Evolution of low birth weight based on support.

\begin{tabular}{|c|c|c|c|c|c|}
\hline Support elements & Death & Cure & Unknown & Total & Value of $p$ \\
\hline \multicolumn{6}{|c|}{ Care centres } \\
\hline Kara Teaching Hospital & 44 & 141 & 24 & 209 & 0,135 \\
\hline Regional Hospital of Kara-Tomdè & 18 & 95 & 20 & 133 & \\
\hline SOS-VE Children and mother Hospital & 23 & 66 & 20 & 109 & \\
\hline \multicolumn{6}{|c|}{ Global diagnosis } \\
\hline Hypotrophy/isolated prematurity & 33 & 117 & 24 & 177 & 0,48 \\
\hline Neonatal infection & 44 & 173 & 33 & 250 & \\
\hline Neonatal Suffering & 8 & 12 & 7 & 27 & \\
\hline \multicolumn{6}{|c|}{ Glucosate serum infusion } \\
\hline Yes & 25 & 57 & 17 & 99 & 0,032 \\
\hline No & 60 & 245 & 47 & 352 & \\
\hline \multicolumn{6}{|c|}{ Type of milk given to newborn baby } \\
\hline Breast milk & 20 & 156 & 21 & 197 & 0,0001 \\
\hline Artificial milk & 8 & 5 & 2 & 15 & \\
\hline Breast milk and artificial milk & 2 & 7 & 0 & 9 & \\
\hline Unspecified & 55 & 134 & 41 & 230 & \\
\hline \multicolumn{6}{|c|}{ Weight gained } \\
\hline Yes & 5 & 158 & 21 & 183 & 0,49 \\
\hline No (stationary weight or loss) & 7 & 149 & 34 & 180 & \\
\hline Unspecified & 73 & 0 & 9 & 88 & \\
\hline \multicolumn{6}{|c|}{ Duration of hospitalization (in day) } \\
\hline$[0-7]$ & 57 & 193 & 56 & 306 & 0,0000002 \\
\hline$[8-30]$ & 2 & 109 & 6 & 117 & \\
\hline Unspecified & 26 & 0 & 2 & 28 & \\
\hline \multicolumn{6}{|l|}{ Age of exit in daylight } \\
\hline$[0-7]$ & 42 & 164 & 46 & 252 & 0,00012 \\
\hline$[8-31]$ & 8 & 138 & 18 & 160 & \\
\hline Unspecified & 35 & 0 & 4 & 39 & \\
\hline
\end{tabular}

\section{Discussion}

The retrospective nature of this study did not allow the collection of certain data related to incomplete files filling and the imprecision of certain diagnoses. Beyond these, this study provides an overview of LBWs' support in Kara that can serve as a starting point for future studies on the subject.

Epidemiological aspects- LBWs new borns accounted for $30.8 \%$ of hospitalized newborns, as reported in a previous study $(29.71 \%)$ in the same ward [9]. In 2002, premature infants accounted for $11.1 \%$ in Lomé (Togo) out of 1672 live births [8]. This frequency varied in Africa from $8.5 \%$ in Nigeria [10] to $15.1 \%$ in Madagascar in 2010 [11] for premature births. This high frequency of LBWs at Kara is explained by its report only to hospitalized newborns and highlights the weight and the problems associated with the support of these LBW newborns.

Diagnostic aspects- LBWs' mothers were in 31.9\% of the cases primiparous women and $14.44 \%$ were multiparous. Primiparity especially among young mothers and multiparity are reported as predictors of LBW $[8,10,11]$. Abortions (30 cases) and HBP (10 cases) were the dominant antecedents among mothers of the LBWs: abortions were reported in $44.25 \%$ in 2005 in Nigeria [10] while the HBP ranked first in Tanzania [12]. In 2002, in Lomé, maternal pathologies as infections (36\%), malaria (22\%) and ovular abnormalities (12 to $34 \%$ ) were the conditions associated with premature infant in the study of Balaka et al. These authors have also 
reported a pathological obstetric history (17.2\%), voluntary abortion (11.3\%), inadequate prenatal monitoring (66.6\%), a low level of education $(38.7 \%)$ and excessive physical activity $(29 \%)$ as factors significantly related to prematurity [8]. The importance of pathologies associated with LBW seems to depend on geographical regions, socioeconomic level and diagnostic means.

The averageof antenatal visits during pregnancy was 2.79: this deficiency in pregnancy follow-up is accentuated in developing countries, where unfavorable socio-economic conditions influence pregnancy follow-up and would favor LBW [13-14]. Multiple pregnancies, one of the LBWs'causes $(23.1 \%)$, was also reported in a less proportion $(17.7 \%)$ in Lomé [8]. Compared to delivery, caesarean section was reported in $16.9 \%$ in this study with the main indication of pregnancy toxemia (29.5\%). Vaginal delivery could have been the preferred mode of delivery of LBW because of the smallness of the fetal motive. The caesarean section is the sanction in relation to specific or general causes that may endanger the life of the mother and the already fragile newborn.

Clinically, 29.9\% (135 cases) of hypothermia were found as in the case of the $29.0 \%$ found on admission in Ghana [15]. It may be linked to a failure of its prevention or to a neonatal infection and should be sought for better care. Neonatal infections (55.4\%) and perinatal asphyxia (12.9\%) were the two main associated comorbidities in the LBWs. The importance of perinatal asphyxiain neonatal deaths has for some years now justified the resuscitation trainings "Help Baby Breath" [16].

Support and evolution of LBW infants- The average time taken to transfer LBW newborns was 12 hours for referral from another centre. This delay seems relatively long due to insufficient medical means of transportation and the financial resources of the parents who provide the care themselves. All actors must work to act on the different types of delays (decision-making, consultation, diagnosis and support) in order to improve the care and lbw prognosis.

Three-quarters of the LBWs have received antibiotic therapy, with neonatal infection being one of the most common causes of LBW[1,4] but paraclinical confirmation is sometimes difficult to achieve in

\section{Original Research Article}

ourregions. It is necessary for services to have a neonatal infection care protocol to which staff is trained to avoid complications and death.

Parenteral nutrition with lipid and protein substances is limited in this context while the risk of dehydration and hypoglycemia remains high: $78.05 \%$ of the LBW newborns were hydrated with glucose and ionic salts without a defined protocol. As a result of this limitation, LBW feeding has become more dependent on breastfeeding when conditions permit or artificial milk for premature infants if breastfeeding is not feasible. It is essential that a fairly precise way of feeding the LBW newborn be set up to enable the paramedicalteam to carry it out.

For the warming-up of the LBW newborn, the KMCs were mentioned in $30.2 \%$ contrary to the use of incubators or warming plates (76.7\%). Several studies have demonstrated the clinical, therapeutic, evolutionary, psycho-affective and socio-economic benefits of KMC [17]. KMCs make it possible to compensate for the lack of material, financial and human resources: their extension in our neonatology services would significantly reduce LBW newborns mortality.

Per the progress, LBW newborns were discharged on the recommendation of a medical doctor in $67 \%$ for an average hospitalization period of 6.07 dayswith longer stays depending on very and extreme LBW[8]. The relatively short period of stay of our LBW newborns could be explained by an improvement in the care provided, related to the introduction of $\mathrm{KMC}$, but above all by a limitation in the availability of places, outings due to parents' financial restrictions. The trend was deadly in $18.8 \%$, far less than $30.1 \%$ in preterm infants during the year 2002 in Lomé, where the risk of death is twice as high $(60.9 \%)$ in premature infants under 31 weeks of pregnancy and three times higher $(93.7 \%)$ in LBW newborns of less than $1000 \mathrm{~g}[8]$. The death rate in this study, however, shows all the potential of KMC method.

Predictive evolutionary factors of low birth weight mortality- Mortality in LBW newborns was statistically related to the early neonatal period, low sucking, hypotonia, high prematurity, very LBW, insufficient prenatal visits and pregnancy monitoring, referrals, perinatal asphyxia, artificial 
breastfeeding and to the first week of hospitalization. The results are similar to those commonly found in the literature where other factors such as maternal backgrounds and neonatal infections have also been mentioned [7-8]. LBW infants are poorly tolerant of labor and vaginal delivery; they have a higher incidence of asphyxia, more pronounced in the premature than the hypotrophic infant, resulting in early and effective treatment [18].

Extramural transfers of newborns, especially LBW newborns, area significant risk of neonatal mortality: in Cameroon in 2006, newborns in contact with the outside environment had $26.4 \%$ mortality rate compared to $16.1 \%$ in the group that had not been exposed [18]. Often non-medicalized non-aseptic birth and transfer conditions expose newborns to infections and other complications such as hypothermia and hypoglycemia.

The first week of admission and artificial breastfeeding were significantly related to death causing an effective intensive care management and feeding of the LBW newborn problem at the beginning of hospitalization. This justifies an improvement in the care of newborns at birth as well as the availability of qualified personnel in the various structures to improve the prognosis of the LBW.

\section{Conclusion}

Various avoidable factors have been linked to LBW occurrence such as poor pregnancy monitoring, previous abortion, eclampsia and HBP. The main comorbidities were neonatal infection and perinatal asphyxia.LBW newborn's management has been limited by the insufficiency of the technical and therapeutic facilities. In the absence of a remarkable improvement in the socio-economic status of populations, linked to the global economic situation, an integrated development program for perinatal medicine taking local realities into account could help to improve the prognosis of LBWneonates in developing countries.The survival of the LBWdepends on the availability of neonatal care unit in the centre. Pregnancy women must be educated to avoid LBW and complicationsrelated to these fragile babies.

Keys words:low-birth-weight, newborn, morbidity, outcomes, Togo.
Funding: Nil, Conflict of interest: None initiated, Perission from IRB: Yes

Add a list of abbreviations used at the end of the article before the reference

HPB (high blood pressure cases), LBW (Low-birthweight), KMC (Kangaroo Maternal Care)

\section{Contribution by authors}

1. AZOUMAH KD: concept, analysis, editing and supervision

2. SEGBEDJI KAR: data acquisition, analysis, editing,

3. DOUTI KN: data analysis, editing.

4. AHOUANKPO KA: data acquisition, analysis, writing.

5. TCHAGBELE OB: data analysis, editing,

6. GERALDO A: drafting of the work, writing;

7. DOUAGUIBE B: drafting of the work, writing

8. BALAKA B: analysis, editing.

9. AGBERE AD: Concept and supervision.

\section{References}

1. Oza S, Lawn JE, Hogan DR, Mathers C, Cousens SN. Neonatal cause-of-death estimates for the early and late neonatal periods for 194 countries: 20002013.Bulletin of the World Health Organization 2015; 93:19-28. doi: http://dx.doi.org/10.2471/BLT. 14.139790 .

2. Black RE, Victora CG, Walker SP, Bhutta ZA, Christian P, De Onis M et al. Maternal and Child Nutrition Study Group. Maternal and child undernutrition and overweight in low-income and middle-income countries. Lancet. 2013 Aug 3;382 (9890): 427-451. doi: 10.1016/S0140-6736(13) 60937-X. Epub 2013 Jun 6.

3. Katz J, Lee AC, Kozuki N. Mortality risk in preterm and small-for-gestational-age infants in low-income and middle-income countries: a pooled country analysis. Lancet. 2013 Aug 3;382 (9890): 417-425. doi: 10.1016/S0140-6736(13) 60993-9.

4. Oestergaard MZ, Inoue M, Yoshida S, Mahanani WR, Gore FM, Simon C, et al. On behalf of the United Nations Inter-agency Group for Child Mortality Estimation and the Child Health Epidemiology Reference Group: Neonatal mortality levels for 193 countries in 2009 with trends since 
1990: a systematic analysis of progress, projections, and priorities. PLoS Med. 2011 Aug;8(8):e1001080. doi: 10.1371/journal.pmed.1001080. Epub 2011 Aug 30.

5. Rajaratnam JK, Marcus JR, Flaxman AD, Wang H L-R A, Dwyer L, Lopez AD, et al. Neonatal, postneonatal, childhood, and under-5-mortality for 187 countries, 1970-2010; a systematic analysis of progress towards Millennium Development Goal 4. Lancet 2010, 375:1988-2008.

6. Ministère de la Planification, du Développement et de l'Aménagement du Territoire (MPDAT), Ministère de la Santé (MS) et ICF International. Enquête Démographique et de Santé au Togo 20132014. Maryland, USA: MPDAT, MS et ICF International, 2015.

7. Djadou KE, Takassi OE, Guedéhoussou T, Faiwoo KM, Guedénon KJ, Atakouma YD. Facteurs liés au petit poids de naissance au Togo. Méd Périnat 2017. DOI 10.1007/s12611-017-0437-5.

8. Balaka B, Baeta $\mathrm{S}$, Agbèrè AD, Boko K, Kessie $\mathrm{K}$, Assimadi K. Facteurs de risque associés à la prématurité au CHU de Lomé, Togo. Bull Soc Pathol Exot. 2002 Nov; 95(4): 280-3.

9. Azoumah KD, Balaka B, Aboubakari AS, Matey $\mathrm{K}$, Yolou A, Agbèrè AD. Morbidité et mortalité néonatales au CHU Kara (Togo). Méd Afr Noire 2010; 57 (2) : 109 -12.

10. Etuk SJ, Etuk JS, Oyo-Ita AE. Factors influencing the incidence of pre-term birth in Calaba, Nigeria. Niger J Physiol Sci 2005; 20 (1-2): 63-8.

11. Rabesandratana M, Hanitriniaina L, Randriamanantena R, Rafaralado L, Randasharison P, Andrianarimanana D. Profil épidémio-clinique des nouveau- nés prématurés au CHU Mahajanga Revue Electronique en Sciences de la Santé 2010 May; (1):70-9.

12. Siza JE. Risk factors associated with low weight of neonates among pregnant women attending a referral hospital in Northern Tanzania. Tanzania J Health Res 2008; (10) 1: 1-8.

13. Ndiaye O, Diallo DBa MG, Diagne I, Moreau JC, Diadhiou F. Facteurs de risques maternels et petit poids du nouveau-né chez les adolescents sénégalais: l'exemple d'un centre hospitalier de Dakar. Santé 2001; (11) 4: 241-4.

14. Negi KS, Kandpal SD, Kukreti M Epidemiological Factors Affecting Low Birth Weight. JK Sci. 2006; 8 (1): 31-4.

15. Kanmiki E, Bawah A, Agorinha I, Achana F, John K, Abraham R, et al. Socioeconomic and demographic determinants of under-five mortality in rural northern Ghana. BMC Int Health Hum Rights. 2014 Aug 21; 14:24.

16. Tchagbele OB, Azoumah KD, Segbedji KAR, Kpegouni M, Djadou KE, Balaka B, Atakouma $\mathrm{DY}$, Agbèrè AD. Évaluation des compétences des prestataires de soins exerçant dans les maternités en matière de réanimation néonatale au Togo. Rev Méd Périnat 2015; 7 : 245-53.

17. Whitelaw A, Stealth K. Myth of the marsupial mother: home care of very low birth weight babies in Bogota, Colombia. Lancet 1985; 1: 1206-8.

18. Eloundou OE. Etiologies et facteurs aggravant la morbidité et la mortalité néonatales à l'Hôpital Gynéco-Obstétrique et Pédiatrique de Yaoundé (HGOPY). Thèse de Méd. Faculté de Médecine et des Sciences Biomédicales-Université de Yaoundé I 2006.

\section{How to cite this article?}

Azoumah K.D, Segbedji K.A.R, Douti K.N, Ahouankpo K.A, Tchagbele O.B, Geraldo A, Douaguibe B, Balaka B, Agbere A.D. Low birth weight newborn: epidemiological, therapeutic and evolutive aspects in the commune of Kara (TOGO) from 2014 to 2015.Int J Pediatr Res. 2017;4(12):746-753.doi:10. 17511/ijpr.2017.i12.08. 